\title{
Induction of Central Host Signaling Kinases during Pneumococcal Infection of Human THP-1 Cells
}

\author{
Thomas P. Kohler*, Annemarie Scholz, Delia Kiachludis and Sven Hammerschmidt \\ Department Genetics of Microorganisms, Interfaculty Institute for Genetics and Functional Genomics, Ernst-Moritz-Arndt \\ Universität Greifswald, Greifswald, Germany
}

OPEN ACCESS

Edited by:

Guangchun Bai,

Albany Medical College, USA

Reviewed by:

Kishore Alugupalli,

Thomas Jefferson University, USA

Glen C. Ulett,

Griffith University, Australia

Jose Yuste,

Instituto de Salud Carlos III, Spain

*Correspondence:

Thomas P. Kohler

kohlert@uni-greifswald.de

Received: 25 January 2016 Accepted: 13 April 2016

Published: 26 April 2016

Citation:

Kohler TP, Scholz A, Kiachludis D and Hammerschmidt S (2016) Induction of Central Host Signaling Kinases during

Pneumococcal Infection of Human THP-1 Cells.

Front. Cell. Infect. Microbiol. 6:48. doi: 10.3389/fcimb.2016.00048
Streptococcus pneumoniae is a widespread colonizer of the mucosal epithelia of the upper respiratory tract of human. However, pneumococci are also responsible for numerous local as well as severe systemic infections, especially in children under the age of five and the elderly. Under certain conditions, pneumococci are able to conquer the epithelial barrier, which can lead to a dissemination of the bacteria into underlying tissues and the bloodstream. Here, specialized macrophages represent an essential part of the innate immune system against bacterial intruders. Recognition of the bacteria through different receptors on the surface of macrophages leads thereby to an uptake and elimination of bacteria. Accompanied cytokine release triggers the migration of leukocytes from peripheral blood to the site of infection, where monocytes differentiate into mature macrophages. The rearrangement of the actin cytoskeleton during phagocytosis, resulting in the engulfment of bacteria, is thereby tightly regulated by receptor-mediated phosphorylation cascades of different protein kinases. The molecular cellular processes including the modulation of central protein kinases are only partially solved. In this study, the human monocytic THP-1 cell line was used as a model system to examine the activation of Fc $\gamma$ and complement receptor-independent signal cascades during infection with S. pneumoniae. Pneumococci cultured either in chemically defined or complex medium showed no significant differences in pneumococcal phagocytosis by phorbol 12-myristate 13-acetate (PMA) differentiated THP-1 cells. Double immuno-fluorescence microscopy and antibiotic protection assays demonstrated a time-dependent uptake and killing of S. pneumoniae 35A inside of macrophages. Infections of THP-1 cells in the presence of specific pharmacological inhibitors revealed a crucial role of actin polymerization and importance of the phosphoinositide 3-kinase (PI3K) and Protein kinase B (Akt) as well during bacterial uptake. The participation of essential host cell signaling kinases in pneumococcal phagocytosis was deciphered for the kinase Akt, ERK1/2, and p38 and phosphoimmunoblots showed an increased phosphorylation and thus activation upon infection with pneumococci. Taken together, this study deciphers host cell kinases in innate immune cells that are induced upon infection with pneumococci and interfere with bacterial clearance after phagocytosis.

Keywords: Streptococcus pneumoniae, phagocytosis, THP-1 cells, cell signaling, p38, Akt, PI3K, ERK1/2 


\section{INTRODUCTION}

Streptococcus pneumoniae is a common colonizer of the upper respiratory tract of human, with increased colonization rates in children and the elderly (Garenne et al., 1992; Bogaert et al., 2004b; Hussain et al., 2005). Beside its role as a harmless colonizer, pneumococci are also a common cause of otitis media, pneumonia, meningitis and sepsis, especially in children under the age of 5 years (Bogaert et al., 2004a; Sleeman et al., 2006). S. pneumoniae possesses a wide variety of virulence factors to colonize the host, invade into tissues and to evade the human immune system (Jonsson et al., 1985; Gamez and Hammerschmidt, 2012; Voss et al., 2012). The epithelia of the upper respiratory tract of human represent thereby a physical barrier which needs to be conquered in the process of invasive pneumococcal diseases. Pneumococci therefore release amongst others pneumolysin, neuraminidase, and hyaluronidase to the environment, leading to disruption of connective tissues and extracellular matrices, promoting dissemination of the bacteria into underlying tissues, and the blood system (Kelly and Jedrzejas, 2000; Feldman et al., 2007; Trappetti et al., 2009; Mitchell and Mitchell, 2010). In this scenario, phagocytic cells play an essential role in the recognition and clearance of bacterial infections (van Furth and Cohn, 1968; van Furth et al., 1972). Macrophages represent an important link between the innate and the acquired immune system due to the possibility to phagocytose and digest bacteria and to present part fragments of processed bacteria in association with major histocompatibility complex (MHC) class I or II to Tcells (Greenberg and Grinstein, 2002). Bacterial recognition and uptake by macrophages can be initiated by the activation of different surface receptors. Fc receptor-mediated phagocytosis is initiated by recognition of immunoglobulin $\mathrm{G}$ ( $\mathrm{IgG}$ ) opsonized microorganisms. Here, members of the Fc $\gamma$ receptor family are able to recognize and bind the constant $\mathrm{Fc}$ region of IgG molecules that opsonize pathogenic microorganisms (Gomez et al., 1994; Ravetch, 1997). Microorganisms can also be opsonized for complement receptor-mediated phagocytosis by proteins of the complement system, like $\mathrm{C} 3 \mathrm{~b}$ or $\mathrm{C} 4 \mathrm{~b}$, resulting from cleavage of complement factors (Ghiran et al., 2000).

Besides recognition of opsonized microorganisms, cells of the innate immune system have the capability to sense bacteria directly via their target specific molecular structures, the so called pathogen-associated molecular patterns (PAMPs) via pattern recognition receptors (PRRs). These receptors are located on the surface of host cells, intracellularly and are also be secreted (Janeway and Medzhitov, 2002; Iwasaki and Medzhitov, 2015). For the recognition of pneumococci various PRRs have been described, including the C-reactive protein (CRP), members of the toll-like receptor family (TLRs), Nod proteins, the LPS binding protein (LBP), and CD14 (Mold et al., 2002; Weber et al., 2003; Currie et al., 2004; Echchannaoui et al., 2005; Malley et al., 2005). Furthermore, the C-type lectin SIGN-R1 and the scavenger receptor MARCO, both expressed by macrophages, have been described as PRRs important for the recognition of pneumococci (Arredouani et al., 2004; Kang et al., 2004).
However, recognition of bacteria via PAMPs and sensing of opsonized bacteria leads to the initiation of signal transduction cascades catalyzed by different protein kinases ending up in the activation of proteins involved in actin remodeling and therefore phagocytosis (Freeman and Grinstein, 2014). Nevertheless, the molecular process of actin remodeling during phagocytosis is only partially understood and best studied in Fc $\gamma$ and complement-3 receptor-(CR3) mediated phagocytosis.

The signaling network of protein kinases involved in phagocytosis is rather complex and dependent from the activated surface receptors and cross-talk between different signaling pathways.

Members of the phosphoinositide-3-kinase (PI3K) family are essential for many cellular processes by transducing outsideinside signaling. Amongst others, this signaling leads to the activation of downstream effector pathways, including the reorganization of the cytoskeleton via exchange factors that regulate the small GTPase Rac and activation of the protein kinase $\mathrm{C}(\mathrm{PKC})$ as well as the serine/threonine protein kinase $\mathrm{B}$ (PKB/Akt) (Hawkins et al., 1995; Katso et al., 2001; Engelman et al., 2006). Moreover, experiments with pharmacological inhibitors of the PI3K (Wortmannin and LY294002) revealed also an essential role in FC $\gamma$ and complement receptor-mediated phagocytosis (Cox et al., 1999; Aderem, 2003). Blocking of the PI3K leads not to an inhibition of opsonized particle binding or initial actin polymerization but seems to be required for membrane extension and fusion during engulfment (Araki et al., 1996; Cox et al., 1999).

Another important component of intracellular signaling processes is the protein kinase B (Akt), a serine/threonine (Ser/Thr) protein kinase involved in a wide variety of signaling pathways concerning such as cell growth, survival, or cellular metabolism (del Peso et al., 1997; Wullschleger et al., 2006; Manning and Cantley, 2007). Akt is an important downstream target of the PI3K, and represents therefore a mediator of the PI3K activity, as shown for example by blocking Akt activation using the PI3K inhibitor Wortmannin (James et al., 1996). Also, Akt was further shown to be activated during the process of $\mathrm{FC} \gamma$ receptor-mediated phagocytosis (Ganesan et al., 2004).

A third protein family widely involved in cellular signal transduction pathways is the mitogen-activated protein kinase (MAPK) family. These kinases are also Ser/Thr protein kinases converting extracellular stimuli into a cellular response and they are involved in many physiological processes (Widmann et al., 1999). Examples for conventional MAPKs are the two MAPK isoforms ERK1 and ERK2 which can be activated by a number of different growth factors such as platelet-derived growth factor (PDGF) and epidermal growth factor (EGF) as well as in response to insulin, ligand binding on heteromeric G-protein coupled receptors (GPCR), cytokines, osmotic stress, and microtubule disorganization (Boulton et al., 1990; Raman et al., 2007).

ERK1/2 was shown to be activated during the process of Fc $\gamma$ mediated phagocytosis (Karimi and Lennartz, 1998; Fitzer-Attas et al., 2000). Interestingly, ERK1/2 was shown to be inhibited in the early phase of CR3-dependent bacterial phagocytosis as shown by infection of human macrophages with Francisella tullarensis (Dai et al., 2013). 
The p38 kinases are a further sub-group of the MAPK family, which includes the p38 $\alpha, \beta, \gamma$, and $\delta$ kinases. The p38 kinases are highly activated by cytokines and environmental stress and were shown to be critical for the regulation of immune and inflammatory processes (Cuenda and Rousseau, 2007). Bacterial binding to various TLRs initiates bacterial phagocytosis via signaling cascades involving amongst others p38 (Doyle et al., 2004).

A widely-used model cell line for the analysis of macrophage/pathogen interactions are the human monocytic THP-1 cells. The addition of phorbol 12-myristate 13-acetate (PMA) to the growth medium leads to the differentiation of monocytes into macrophage-like phagocytic cells. Due to their availability of Fc receptors, C3b receptors and various pattern recognition receptors, as well as the lack of surface and cytoplasmatic immunoglobulins, THP-1 cells can be used for immunocytochemical studies (Tsuchiya et al., 1980; Matsumoto et al., 1990).

In this study, the human pathogen S. pneumoniae and human THP-1cells were used to evaluate the role of the bacterial growth medium on phagocytosis, to study the time-dependent uptake of pneumococci and to visualize the intracellular fate over time within the macrophages. On the other hand Fc $\gamma$ - and CR-independent signaling mechanisms during phagocytosis of S. pneumoniae in differentiated THP-1 cells were analyzed. Therefore, infection experiments in the presence of pharmacological inhibitors of actin polymerization, PI3K and Akt were carried out. Furthermore, cell lysates from different time points of infected THP-1 cells were analyzed by immunoblot analysis to identify the participation of important cellular protein kinases involved in cell signaling during pneumococcal phagocytosis.

\section{MATERIALS AND METHODS}

\section{Bacterial Strains, Media, and Culture Conditions}

Streptococcus pneumoniae NCTC 10319 (serotype 35A, low encapsulated) (Pracht et al., 2005) was grown in complex medium Todd-Hewitt broth (Oxoid) supplemented with $0.5 \%$ yeast extract (THY), defined chemical medium RPMI modified (RPMI $\mathrm{mod}_{\text {mo }}$ (Schulz et al., 2014), or on blood agar plates (Oxoid) at $37^{\circ} \mathrm{C}$ and $5 \% \mathrm{CO}_{2}$.

\section{Bacterial Growth Curves}

Bacteria were plated from cryo cultures on blood agar (Columbia agar with sheep blood, Oxoid) and incubated at $37^{\circ} \mathrm{C}$ and $5 \%$ $\mathrm{CO}_{2}$. THY medium or $\mathrm{RPMI}_{\text {mod }}$ (40 $\mathrm{ml}$ in polypropylene tubes) was inoculated with freshly grown bacteria to an initial $\mathrm{OD}_{600}=$ $0.1-0.15$ and incubated without agitation in a water bath at $37^{\circ} \mathrm{C}$. Growth was monitored at appropriate time points by measuring absorbance at $\mathrm{OD}_{600}$ (BioPhotometer, Eppendorf).

\section{Phagocytosis Experiments}

Monocytic THP-1 cells were seeded in 24-well plates $(2 \times$ $10^{5}$ cells per well in RPMI-1640 supplemented with $10 \%$ heat inactivated FCS in a volume of $1 \mathrm{ml}$ ) and differentiation was stimulated by the addition of $200 \mathrm{nmol} / \mathrm{ml}$ phorbol 12 -myristate 13-acetate (PMA) (Sigma-Aldrich). Prior to infection THP-1 cells were incubated for $72 \mathrm{~h}$ at $37^{\circ} \mathrm{C}$ and $5 \% \mathrm{CO}_{2}$. Pneumococci cultured in $\mathrm{RPMI}_{\text {mod }}$ to mid-log phase $\left(\mathrm{OD}_{600}=0.35-0.45\right)$, were centrifuged and washed with infection medium (RPMI1640 , PAA) containing $1 \%$ heat inactivated fetal bovine serum (Gibco).

THP-1 cells were infected with $S$. pneumoniae using a multiplicity of infection (MOI) of 50 bacteria per phagocyte at $37^{\circ} \mathrm{C}$ and $5 \% \mathrm{CO}_{2}$ in infection medium. Bacteria were slightly centrifuged $(2 \mathrm{~min}, 200 \times \mathrm{g})$ onto the cells to initiate a simultaneous contact with phagocytes. Post infection, phagocytes were washed with infection medium and subsequently incubated with Penicillin G (100 units/ml, Sigma-Aldrich) and Gentamicin (0.1 mg/ml, Sigma-Aldrich) for $1 \mathrm{~h}$ at $37^{\circ} \mathrm{C}$ and $5 \% \mathrm{CO}_{2}$. After washing, the phagocytes were lysed using a $1 \%$ saponin solution. The colony forming units ( $\mathrm{cfu}$ ) of released intracellular pneumococci was determined by plating the bacteria in appropriate dilutions on blood agar plates (Hermans et al., 2006; Noske et al., 2009; Hartel et al., 2011).

Phagocytosis was also analyzed in the presence of the pharmacological inhibitors of PI3-kinase (Wortmannin, $50 \mathrm{nM}$ and LY294002 $50 \mu \mathrm{M}$, ENZO Life Sciences), Akt kinase (Akt-inhibitor VIII, 2.5 and $5 \mu \mathrm{M}$, Calbiochem), and actin polymerization (Cytochalasin D, 0.125 and $0.25 \mu \mathrm{M}$, ENZO Life Sciences).

\section{Double Immunofluorescence Staining}

Pneumococci attached to or phagocytosed by PMA-differentiated THP-1 cells were visualized by double immunofluorescence microscopy (DIF). Therefore, THP-1 cells $\left(2 \times 10^{5}\right)$ were seeded on sterile glass cover slips (12 mm, Hartenstein) and cultured at $37^{\circ} \mathrm{C}$ and $5 \% \mathrm{CO}_{2}, 72 \mathrm{~h}$ prior to the infection (in the presence of $200 \mathrm{nmol} / \mathrm{ml}$ PMA) and infected as described above. Post-infection, THP-1 cells were washed with infection medium to remove unbound bacteria and then fixed with $1 \%$ paraformaldehyde (Roth). After blocking with 5\% bovine serum albumin (BSA, Roth), extracellular bacteria were stained using a polyclonal anti-pneumococcal serum (1:200) and secondary goat anti-rabbit IgG coupled to Alexa-Fluor-488 (1:500, Abcam). Intracellular pneumococci were stained with Alexa-Fluor-568 goat anti-rabbit IgG (1:500, Abcam) after permeabilization of the THP- 1 cells with $0.1 \%$ Triton-X-100 (Sigma) (10 min, room temperature) and pneumococcal antiserum as primary antibody (1:200). For the statistical analysis 100 cells per experiment and time point were analyzed for the number of intracellular bacteria.

\section{SDS-Page and Immunoblotting}

To analyze the phosphorylation status of selected host kinases during pneumococcal infection, cell lysates were prepared as followed. THP-1 cells $\left(1 \times 10^{6}\right)$ cells were seeded in 6-well plates in a volume of $2 \mathrm{ml} /$ well. Cells were infected as described above and infection was stopped at different time-points by washing cells with ice-cold infection medium, following cell disruption by the addition of Triton-X-100 lysis buffer $(10 \mathrm{mM}$ TRIS, $100 \mathrm{mM} \mathrm{NaCl}, 1 \mathrm{mM}$ EDTA, $1 \mathrm{mM}$ EGTA, $1 \mathrm{mM} \mathrm{NaF}$, $20 \mathrm{mM} \mathrm{Na}_{4} \mathrm{P}_{2} \mathrm{O}_{7}, 2 \mathrm{mM} \mathrm{Na}_{3} \mathrm{VO}_{4}, 0.1 \%$ SDS, 1\% Triton-X-100, 
$10 \%$ glycerin, $0.5 \%$ sodium deoxycholate) supplemented with a protease inhibitor (Complete ${ }^{\circledR}$, Roche). Afterwards, plates were incubated on ice for $10 \mathrm{~min}$ followed by sonication $(2 \times 30 \mathrm{~s})$. After centrifugation $\left(18,234 \times \mathrm{g}, 10 \mathrm{~min}, 4^{\circ} \mathrm{C}\right)$ protein concentration of the supernatant was determined using the Bradford assay (Sigma) and stored at $-20^{\circ} \mathrm{C}$. Cell lysates (50 $\mathrm{\mu g} / \mathrm{sample}$ ) were separated by sodium dodecyl sulfate polyacrylamide gel electrophoresis (SDS-PAGE) on 12\% gels. Proteins were transferred on a nitrocellulose membrane (GE Healthcare) by semi-dry blotting. After transfer, the membrane was blocked overnight at $4{ }^{\circ} \mathrm{C}$ in TBS $+5 \%$ skim milk (Roth). Immunodetection was carried out using specific primary and horse radish peroxidase-(HRP)-conjugated secondary antibodies (listed in Table 1). A primary antibody against glycerinaldehyde3-phosphate dehydrogenase (GAPDH) was used as a loading control. Luminol was used as substrate for HRP. Detection was carried out using a chemiluminescence-detecting camera (ChemoCam, INTAS).

\section{Statistics and Quantitative Analysis of Immunoblots}

All data are reported as the mean \pm SD. Statistical analysis was performed with unpaired, two-tailed Student's $t$-test using GraphPad Prism ${ }^{\circledR}$ software v5.01. In all analyzes a $p<0.05$ was considered statistically significant.

The image processing program ImageJ was used for quantificational analysis of immunoblots by densitometry (Girish and Vijayalakshmi, 2004; Schneider et al., 2012).

\section{RESULTS}

\section{Influence of Bacterial Growth Medium on Pneumococcal Phagocytosis by THP-1 Cells}

To assess the impact of the bacterial growth medium on pneumococcal phagocytosis by PMA-differentiated THP-1 cells, S. pneumoniae were grown in complex medium (THY) or chemically defined medium $\left(\mathrm{RPMI}_{\text {mod }}\right)$ prior to infection. The growth curves of $S$. pneumoniae in the different growth media (Figure 1A) showed a delayed growth in the chemically defined medium in comparison to the complex medium, which is probably due to the high adaptation of pneumococci to the overall nutrient availability in $\mathrm{RPMI}_{\text {mod }}$. In consequence, pneumococci cultured in THY showed an earlier achievement of the stationary phase and a higher optical density.

Pneumococci used in infection assays were harvested from the exponential growth phase $\left(\mathrm{OD}_{600}=0.35-0.45\right)$. PMAdifferentiated THP-1 cells were infected for $1 \mathrm{~h}$. The number of recovered intracellular surviving bacteria was determined by the antibiotic protection assay. The results revealed no significant influence of the bacterial growth medium on pneumococcal uptake by PMA-differentiated THP-1 (Figures 1B,C).

\section{Kinetics of S. pneumoniae Phagocytosis by THP-1 Cells}

In the results of the antibiotic protection assay a time-dependent increase of phagocytized pneumococci could be observed over time without saturation $90 \mathrm{~min}$ post infection (Figure 2A). In the complementary infection assay, adherent extracellular, and ingested intracellular pneumococci were visualized and illustrated using DIF-staining. Similar to the antibiotic protection assay, an increase of intracellular bacteria was monitored over time as shown by representative microscopic images (Figure 2B). The enumeration of intracellular bacteria in 100 infected THP1 cells using immunofluorescence microscopy confirmed the results of the antibiotic protection assay. This approach also demonstrated a time-dependent increase of intracellular bacteria upon increasing infection times, without reaching saturation 90 min post-infection (Figure 2C).

\section{Intracellular Fate of Phagocytized Pneumococci}

The intracellular fate of $S$. pneumoniae after phagocytosis was analyzed in a time-dependent manner post-infection of THP1 cells. Extracellular bacteria were killed after infection by the addition of antibiotics. The intracellular number of recovered, viable bacteria was determined after lysis of the THP- 1 cells and plating of the bacteria on blood agar plates. The THP-1 cells

TABLE 1 | Antibodies used in this study.

\begin{tabular}{|c|c|c|c|c|}
\hline Antibody & Dilution & MW [kDa] & Source & Company \\
\hline Akt Antibody & $1: 500$ & 60 & Rabbit & Cell Signaling (\#9272) \\
\hline Phospho-Akt (Ser473) & $1: 500$ & 60 & Rabbit & Cell Signaling (\#9271) \\
\hline GAPDH polyclonal antibody & $1: 50,000$ & 36 & Goat & Abnova (\#PAB6637) \\
\hline p44/42 MAPK (ERK1/2) (137F5) & $1: 1000$ & 42,44 & Rabbit & Cell Signaling (\#4695) \\
\hline Phospho-p44/42 MAPK (ERK1/2) (Thr202/Tyr204) & $1: 1000$ & 42,44 & Rabbit & Cell Signaling (\#9101) \\
\hline Goat Anti-Rabbit lgG $(\mathrm{H}+\mathrm{L})$ (Clone: pAb)-HRPO & $1: 500-1: 2500$ & None & Goat & Dianova (\#111-035-045) \\
\hline Polyclonal Rabbit Anti-Goat IgG/HRP & $1: 2000$ & None & Rabbit & Dako (\#P044901-2) \\
\hline Goat Anti-Rabbit lgG H\&L (Alexa Fluor ${ }^{\circledR}$ 488) & $1: 500$ & None & Goat & Abcam (\#ab150077) \\
\hline Goat Anti-Rabbit lgG H\&L (Alexa Fluor ${ }^{\circledR} 568$ ) & $1: 500$ & None & Goat & Abcam (\#ab175471) \\
\hline
\end{tabular}




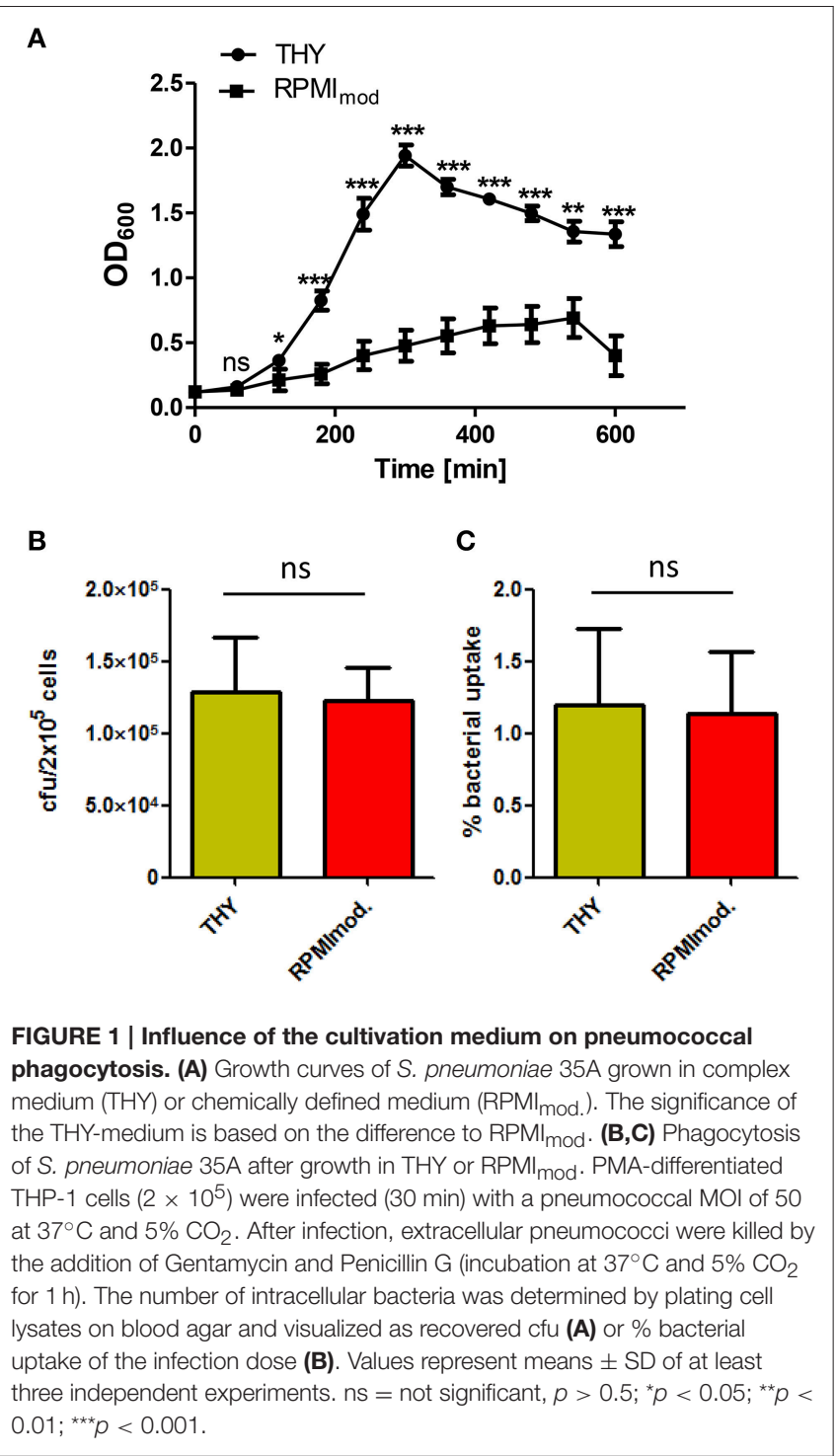

showed a continuous killing of the engulfed pneumococci during the evaluation period as determined by a constant decrease of bacterial cfu over time (Figure 3A). Similar, the DIF-staining and fluorescence microscopy confirmed the results of the antibiotic protection assay (Figures $3 \mathbf{B}, \mathbf{C}$ ). Representative images and numbers of intracellular bacteria within infected THP-1 cells confirmed the decrease of intracellular pneumococci over the observed time period. Taken together, these results revealed an effective time-dependent intracellular killing of phagocytized pneumococci by THP-1 cells.

\section{Inhibition of Pneumococcal Phagocytosis by Inhibitors of Central Host Cell Kinases}

Phagocytosis and hence, the rearrangement of the host cell cytoskeleton requires most likely bacterial binding to cell surface receptors, followed by cell signaling through different protein kinases and finally activation of proteins involved in the reorganization of the cytoskeleton. To demonstrate the
A

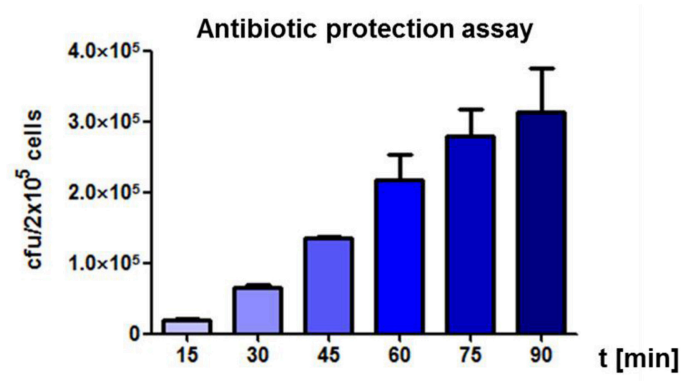

B
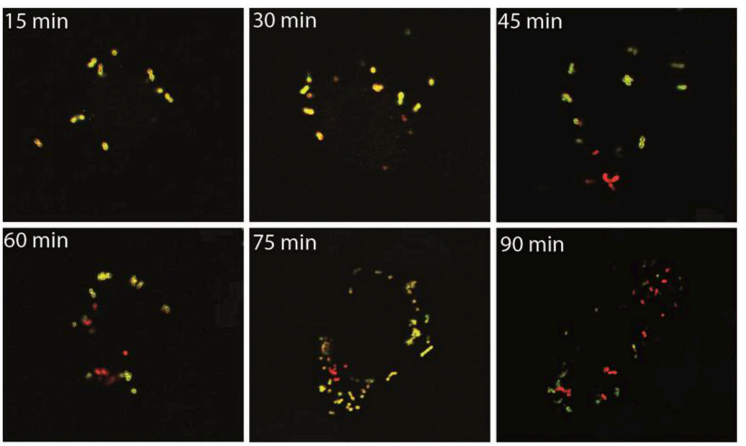

C

Intracellular bacteria



FIGURE 2 | Analysis of the time-dependent phagocytosis of $S$. pneumoniae. (A) Antibiotic protection assay: PMA-differentiated THP-1 cells $\left(2 \times 10^{5}\right)$ were infected with exponential grown S. pneumoniae $35 \mathrm{~A}(\mathrm{MOI}=$ 50). The infection was stopped at different time points (15-90 min) by adding of Penicillin $\mathrm{G}$ and Gentamicin. Intracellular recovered viable pneumococci were quantified after plating cell lysates on blood agar and enumeration of cfu. (B) Double immunofluorescence staining of THP-1 cells at different time-points of infection. Extracellular bacteria were stained using polyclonal anti-pneumococcal antiserum and Alexa-Fluor-488 labeled secondary antibody (green) and after permeabilization of cells with $0.1 \%$ Triton-X 100 intracellular bacteria (red) were stained using a polyclonal anti-pneumococcal antiserum and secondary Alexa-568-labeled antibody. (C) Intracellular pneumococci of 100 infected THP-1 cells on microscopic slides were counted (double immunofluorescence microscopy) at different time points of infection. Values represent means $\pm S D$ of at least three independent experiments.

influence of actin polymerization during phagocytosis, infection experiments were carried out in the presence of Cytochalasin $\mathrm{D}$ (CytoD), a potent inhibitor of actin polymerization. PMAdifferentiated THP-1 cells were infected with S. pneumoniae $35 \mathrm{~A}$ in the presence of different concentrations of CytoD. DIFstaining and immunofluorescence microscopy were applied to visualize the effect of CytoD on the phagocytosis rate. The 


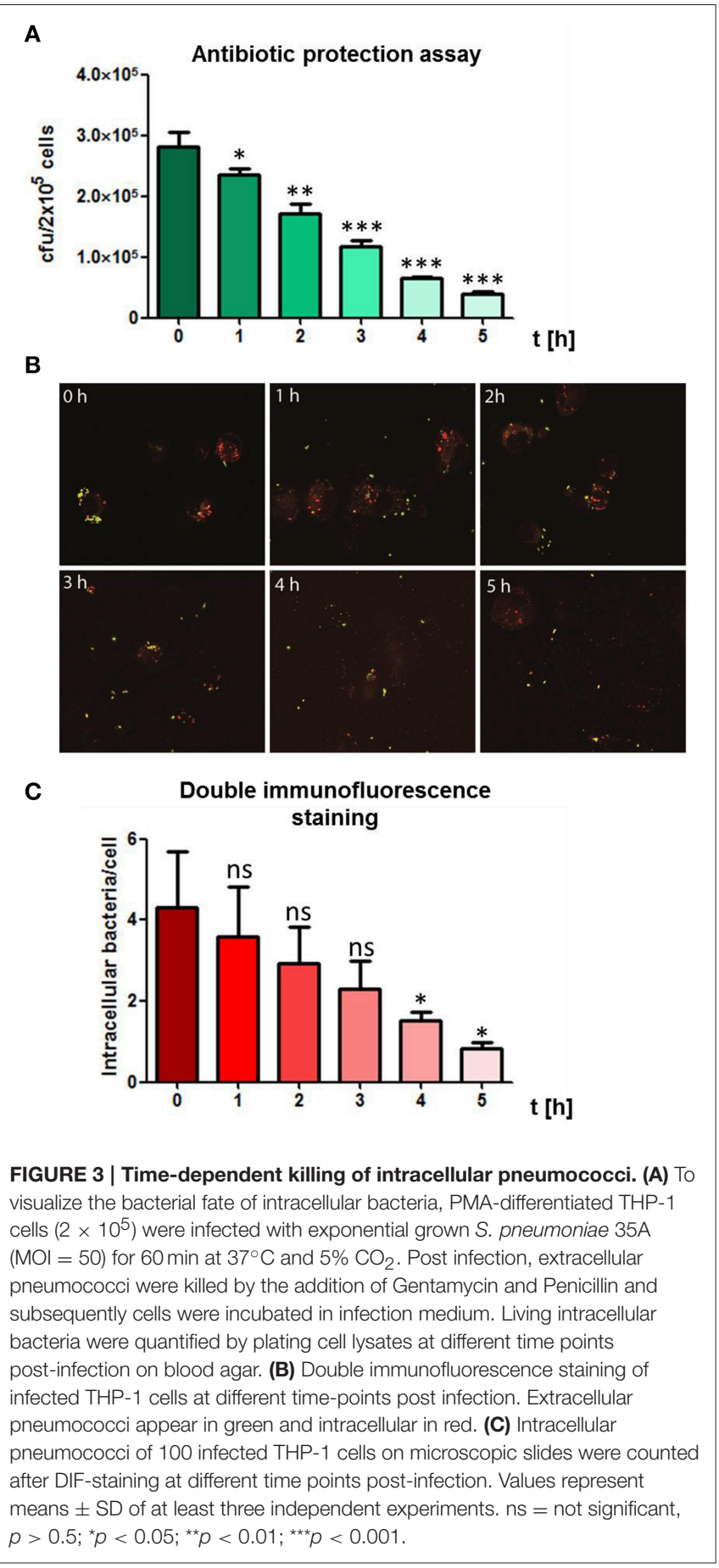

addition of increasing concentrations of CytoD resulted in a dose-dependent decline of intracellular pneumococci within the infected THP-1 cells (Figure 4A). To quantify ingested bacteria the number of intracellular bacteria was enumerated in infected cells by DIF-staining and subsequent immunofluorescence microscopy (Figure 4C). A significant, dose-dependent effect of CytoD on the phagocytosis rate (reduction of intracellular bacteria to 40 and $16 \%$ ) was visible. These results were confirmed with an antibiotic protection assay where the amount of living

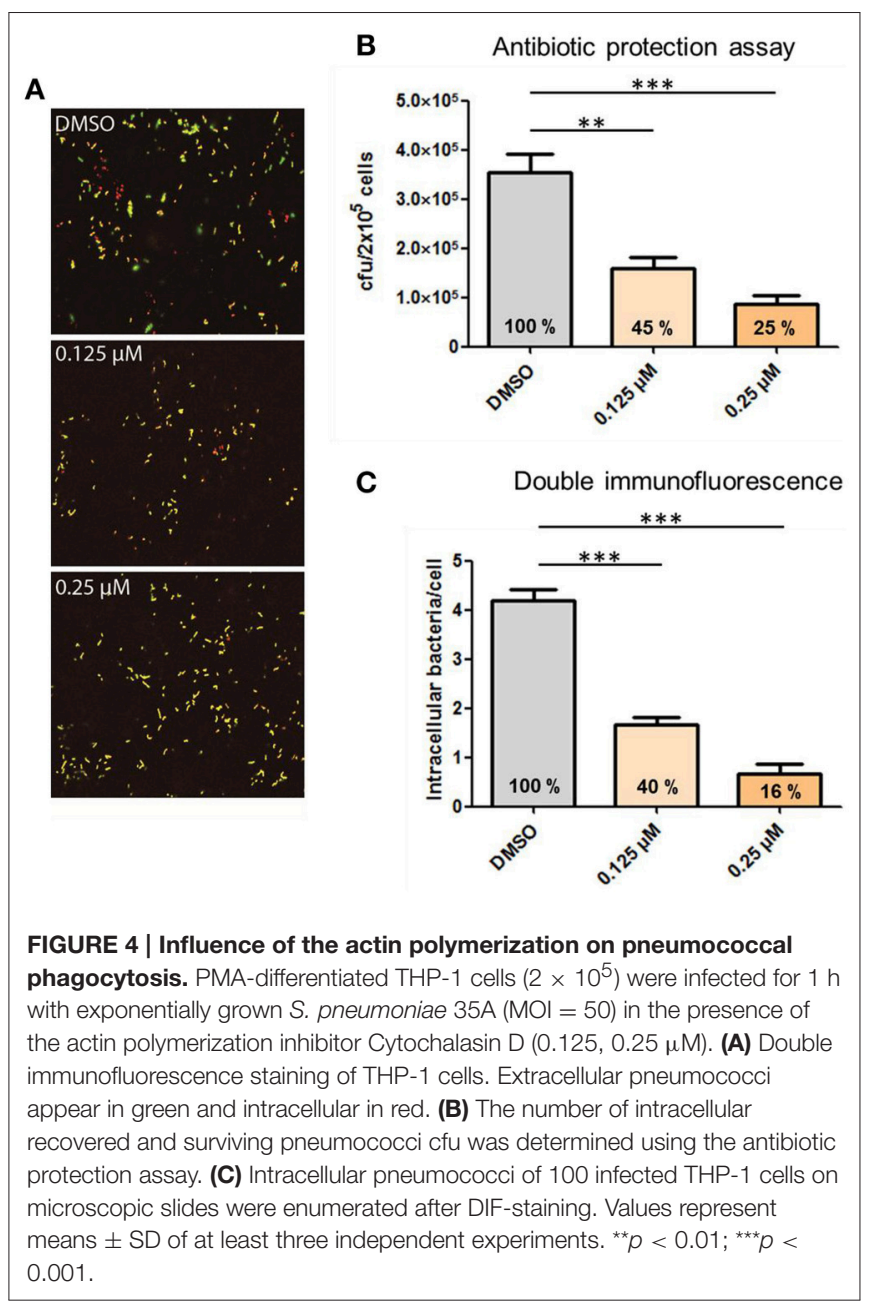

extracellular bacteria significantly declined dose-dependently (45 and 25\%) with increasing concentrations of CytoD (Figure 4B).

This experimental approach was further chosen to analyze the role of the protein kinases PI3K and Akt in the process of pneumococcal phagocytosis by THP-1 cells. The presence of the PI3K inhibitors Wortmannin and LY294002 resulted in a significant inhibition of pneumococcal uptake after 1 $h$ of infection. The microscopic images of the DIF-stained infections (Figure 5A) and counted bacteria within the THP-1 cells (Figure 5C) showed a significant decrease of intracellular bacteria (33 and 30\%) compared to the control cells treated only with DMSO. These results were comparable to the results obtained in the complementary antibiotic protection assay (Figure 5B). To analyze the role of the protein kinase Akt, different concentrations of the Akt inhibitor VIII were used during pneumococcal infection of THP-1 cells. The results of the antibiotic protection assay (Figure 6A) in the presence of Akt inhibitor VIII revealed a dose-dependent decrease of viable intracellular pneumococci (66 and 39\%) with increasing concentrations of the inhibitor. Taken together, these results reflect the essential role of actin polymerization and the involvement of the protein kinases PI3K and Akt in the Fc $\gamma$ 


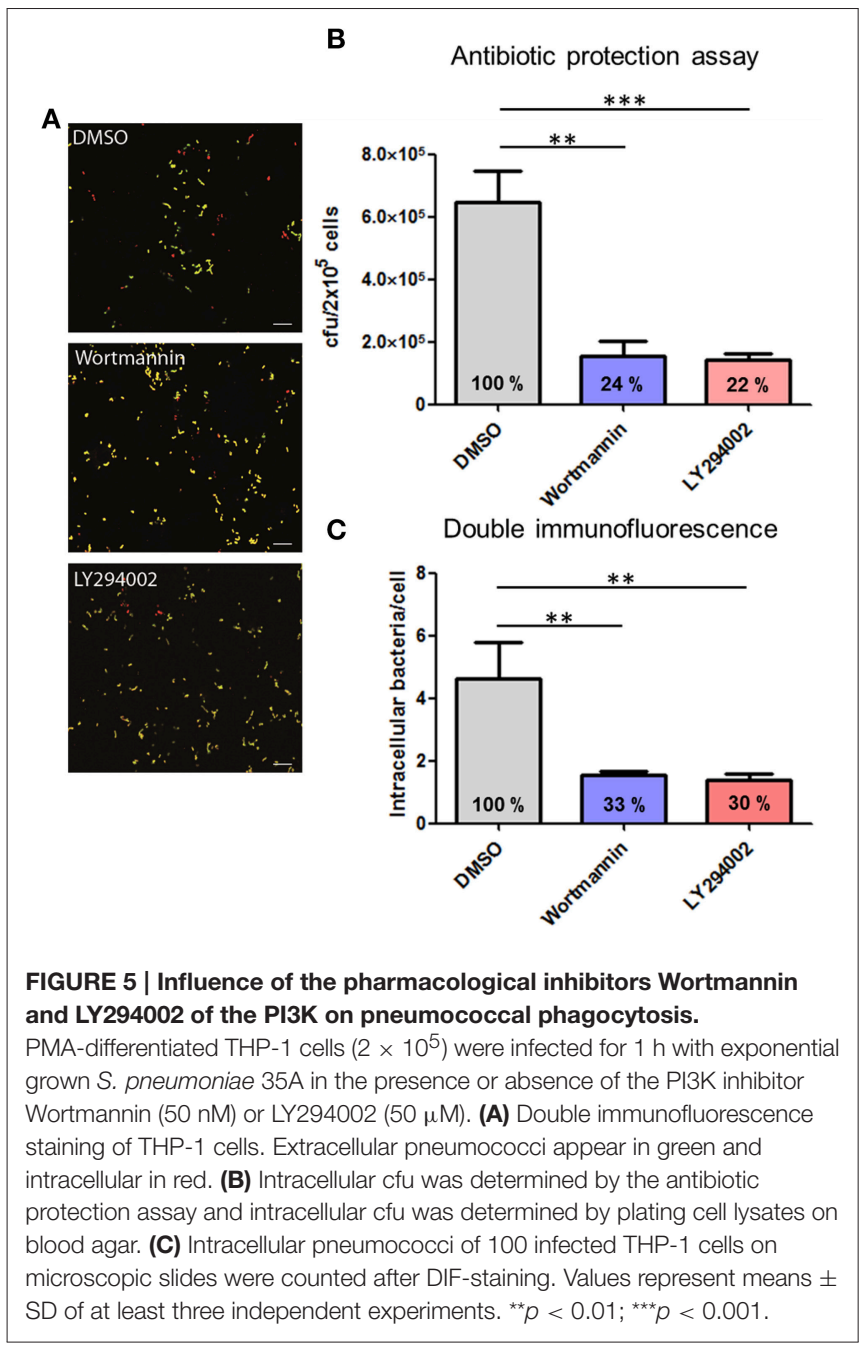

and CR-independent phagocytosis of S. pneumoniae through PMA-differentiated THP-1 cells.

\section{Time-Dependent Phosphorylation of Selected Protein Kinases during Bacterial Phagocytosis}

To evaluate the involvement and time-dependent phosphorylation of various protein kinases during pneumococcal infection, PMA-differentiated THP-1 cells were infected with $S$. pneumoniae for different time periods. Cell lysates were used for SDS-PAGE and immunoblot analysis with specific antibodies against phosphorylated and non-phosphorylated forms of different protein kinases (Table 1). The inhibition of Akt in the presence of Akt inhibitor VIII was already demonstrated to be involved in pneumococcal uptake as shown by an antibiotic protection assay (Figure 6A). The immunoblots of Akt/pAkt indicated an increase in Akt phosphorylation $10 \mathrm{~min}$ post infection with the highest amount after 20 min (Figure 6B). A densitometric approach was chosen to quantify the obtained results from the immunoblot. The analysis reflects thereby the observed increase of the phosphorylated form of Akt as shown in Figures 6 C,D. Moreover, the phosphorylation of the MAPKs ERK1/2 and p38 during pneumococcal uptake was analyzed (Figure 7). Here the amount of phosphorylated ERK1/2 (pERK1/2) starts to increase 20 min post-infection, whereas the amount of phosphorylated p38 (pp38) increases already after 5 min post-infection.

\section{DISCUSSION}

The innate immune system comprises an enormous arsenal of defense strategies to recognize and eliminate foreign microbes, colonizing or invading the human body. These include amongst others physical barriers like epithelia and mucus, secreted enzymes, antimicrobial peptides, and phagocytes (Someya et al., 2013; Sperandio et al., 2015). A critical function of the immune system is the detection and elimination of invading microbes in normally sterile compartments of the human body. In such a case, professional phagocytes recognize microbes amongst others via PRRs, triggering intracellular signal cascades leading in the end to engulfment and elimination of foreign intruders (Silva, 2010).

In this study, we investigated the interaction of pneumococci with macrophage-like, PMA-differentiated THP-1 cells in the absence of human antibodies or complement. This approach allowed us to analyze the host cell response independently of $\mathrm{Fc} \gamma$ or CR-mediated phagocytosis pathways.

Pneumococci have to adapt to various environmental conditions, including nutrient availability, during colonization of mucosal surfaces in humans and invasive infections. Changes in the nutrient composition or availability results in an alteration of intracellular metabolites, influencing regulatory networks and as a consequence gene expression and protein production (Orihuela et al., 2004; Tang, 2011; Schulz and Hammerschmidt, 2013). Pneumococcal growth in a chemically defined medium reflects much more the in vivo situation, in which certain nutrients and/or carbon sources are limited. As shown in the pneumococcal growth curves (Figure 1A), growth was indeed affected due to the limitation of several nutrients. Interestingly, no difference in bacterial uptake through THP-1 cells could be observed using chemically defined $\left(\mathrm{RPMI}_{\bmod }\right)$ or complex medium (THY). This indicates that the composition of surfaceexposed bacterial structures necessary for the recognition and uptake of $S$. pneumonia by THP-1 cells are not substantially changed or reduced due to the composition of the chosen growth media.

Kinetics of pneumococcal phagocytosis by THP-1 cells were analyzed by DIF-staining and subsequent fluorescence microscopy. With this approach, all intracellular bacteria can be visualized, while no differentiation between living and nonviable bacteria is possible. First intracellular pneumococci within THP-1 cells were detected after 15-30 min of infection. The monitored pneumococcal internalization happened in the same time-frame as carried out with other bacteria like $S$. aureus and THP-1 cells (Miller et al., 2011). A saturation in pneumococcal uptake was not observed within the analyzed time period (15$90 \mathrm{~min}$ ), suggesting a higher capacity of THP-1 cells to take up bacteria. 
A

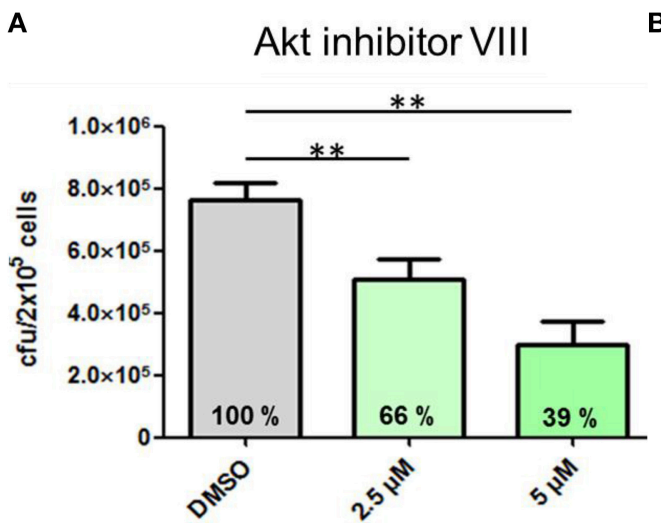

B

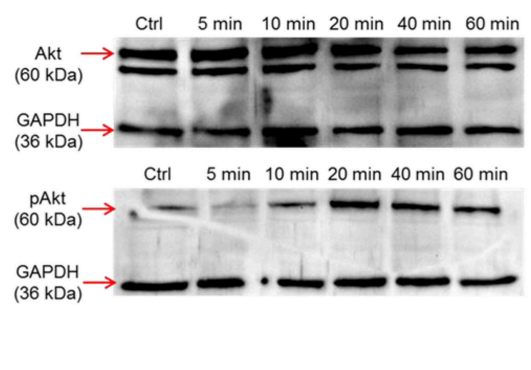

C

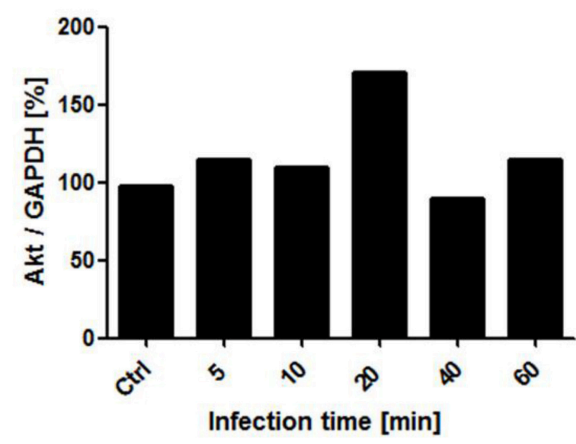

D

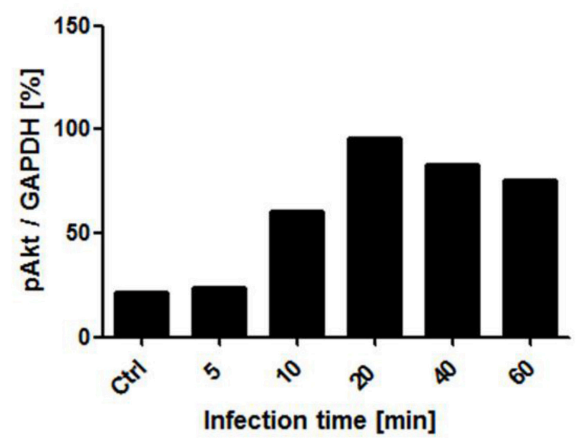

FIGURE 6 | Influence of the pharmacological Inhibitor Akt inhibitor VIII on pneumococcal phagocytosis and cell signaling. (A) Intracellular cfu was determined after infection of PMA-differentiated THP-cells $\left(2 \times 10^{5}\right)$ with S. pneumoniae 35A in the presence of Akt inhibitor VIII $(2.5$, $5 \mu \mathrm{M}$ or DMSO as control) using the antibiotic protection assay and subsequent plating of bacteria on blood agar. (B) Immunoblot analysis of total Akt and pAkt. Cell lysates of different time points post-infection (5 to $60 \mathrm{~min}, \mathrm{Ctrl}=$ uninfected cells) separated using SDS-PAGE and immunoblot analysis. GAPDH was used as a loading control. (C,D) Densitometric quantification of total Akt and pAkt in relation to GAPDH by ImageJ. Values of Figure 4A represent means \pm SD of at least three independent experiments. ${ }^{* *} p<0.01$.

A major virulence factor of $S$. pneumoniae is the polysaccharide capsule protecting the bacteria from phagocytosis (Wood et al., 1946). In our experimental approach, the low encapsulated strain 35A was chosen to facilitate recognition of surface exposed PAMPs by macrophage PRRs. Intracellular killing of bacteria in macrophages takes place in the phagolysosome via proteases, antimicrobial peptides and reactive oxygen and nitrogen species (Garin et al., 2001). Whereas, several bacterial species evolved strategies to survive or escape from phagolysosomes, such mechanisms are unknown for pneumococci. However, it was shown that during pneumococcal phagocytosis by dendritic cells, a minor proportion of the pneumococci escape from the intracellular vacuoles and resides in the cytosol (Noske et al., 2009). The reason or mechanisms for the pneumococcal escape from phagosomes is unknown. For experiments regarding the intracellular fate of the phagocytized pneumococci during infection, one time point was chosen. Pneumococci phagocytized after $1 \mathrm{~h}$ of infection were nearly completely killed within $5 \mathrm{~h}$ post-infection in a time-dependent manner, demonstrating the inability of S. pneumoniae 35A to survive within the macrophages. However, a minor amount of remaining intracellular pneumococcal cfu $5 \mathrm{~h}$ post-infection could be explained with the outbreak of some of the pneumococci from macrophage phagosomes into the cytoplasm.

The participation of the actin machinery and central cellular protein kinases involved in intracellular signaling pathways was analyzed by pneumococcal infection assays in the presence of specific pharmacological inhibitors and immunoblot analysis of THP-1 cell lysates from different time points of infection. The engulfment of pneumococci into phagosomes requires the recognition of the bacteria via surface receptors on THP1cells, activation of signal cascades and in the end remodeling of the cytoskeleton. The inhibition of actin polymerization by Cytochalasin D during phagocytosis leads in the conducted experiments to a dose-dependent reduction of pneumococcal uptake up to $75 \%$. These results underline the essential function of cytoskeleton rearrangement in pneumococcal phagocytosis by PMA-differentiated THP-1 cells.

The PI3K is an essential regulator of phagocytosis as shown for Fc $\gamma$ and CR-mediated phagocytosis (Araki et al., 1996; Cox et al., 1999). The enzyme catalyzes after activation the phosphorylation of phosphatidylinositol 4,5-bisphosphate (PIP2) to phosphatidylinositol 3,4,5-trisphosphate (PIP3) (Domin and Waterfield, 1997). PIP3 was shown to be a key player in signaling 
A

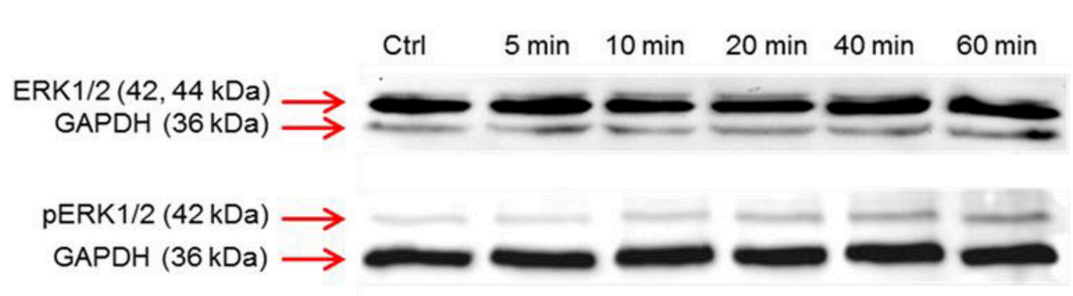

B
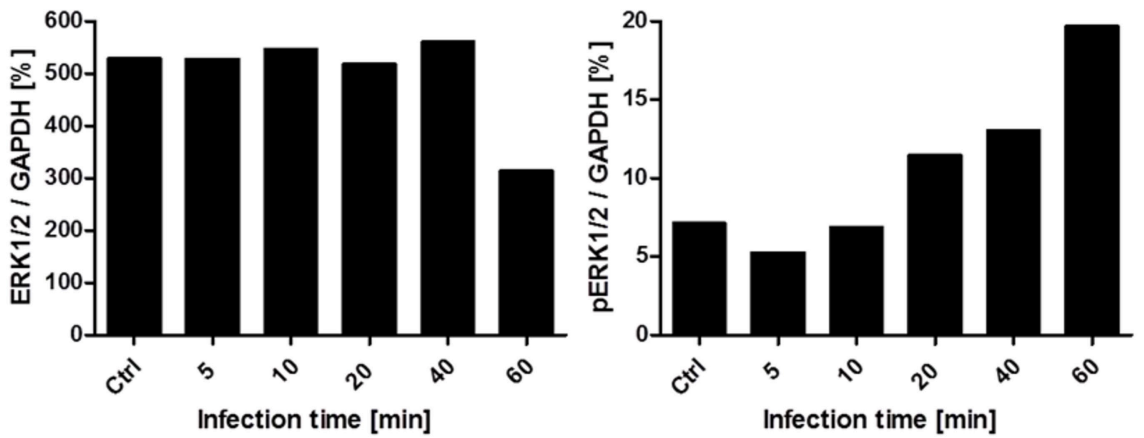

C

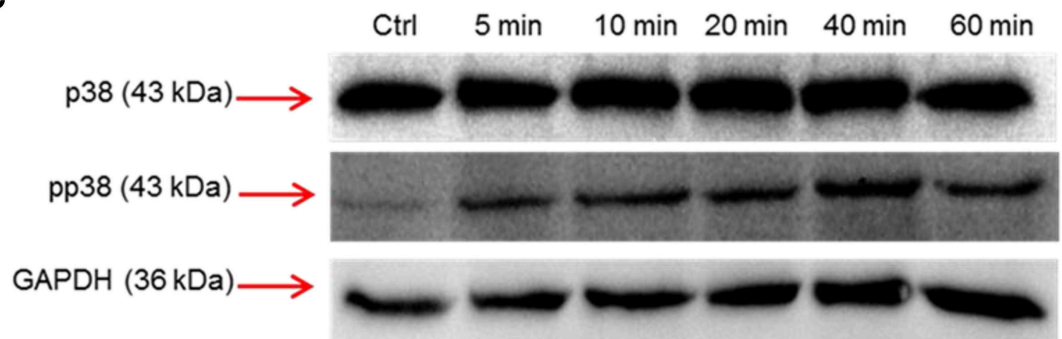

D

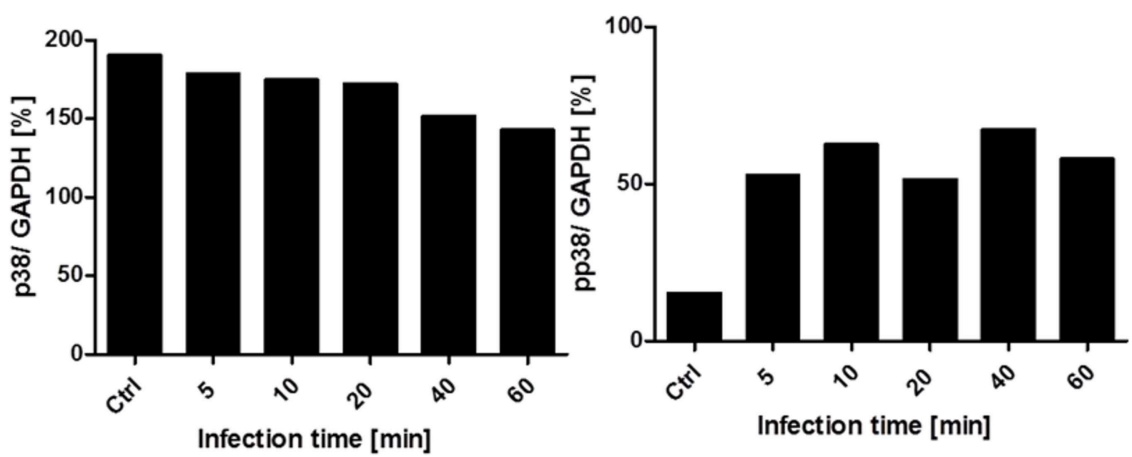

FIGURE 7 | Time-dependent phosphorylation of mitogen-activated protein kinases during pneumococcal uptake. Cell lysates of different time points post-infection (5-60 min, Ctrl = uninfected cells) were analyzed using SDS-PAGE and subsequent immunoblot analysis (antibodies used are listed in Table 1). GAPDH was used as a loading control. (A,B) Immunoblot analysis and densitometric analysis of ERK1/2 and phosphorylated ERK1/2 (pERK1/2) (C,D) Immunoblot and densitometric analysis of p38 and phosphorylated p38 (pp38).

pathways controlling phagocytosis (Gerisch et al., 2009). The activation of the PI3K can, besides others, also occur via PRRs as shown for various TLRs (Arbibe et al., 2000; Monick et al., 2001). Also in our experiments, using non-opsonized pneumococci, inhibition of the PI3K by the pharmacological inhibitors Wortmannin or LY294002 leads to strong decrease in pneumococcal phagocytosis. The protein kinase B (Akt) is one of the major signal transducers, activated by PIP3 of the PI3K (Chan et al., 1999). After $10 \mathrm{~min}$ of pneumococcal infection, the amount of phosphorylated Akt started to increase, with a maximum 
20 min post-infection (Figure 4B). Inhibition of Akt by Akt inhibitor VIII led to a dose-dependent decrease of phagocytized pneumococci within the THP-1 cells. First intracellular bacteria where observed after 15-30 min after infection, which is in concert with the activation of Akt after $10 \mathrm{~min}$, which in turn leads to activation of proteins involved in cytoskeleton rearrangement and therefore engulfment of the pneumococci.

Besides the activation of the PI3K and Akt, we were interested in the activation of the mitogen activated kinases ERK1/2 and p38. The infection of THP-1 cells with $S$. pneumoniae resulted in an increase of pERK1/2 20 min post-infection, without saturation after $60 \mathrm{~min}$. The downstream substrates of ERK1/2 includes amongst others transcription factors, kinases, and cytoskeletal proteins (Yoon and Seger, 2006) involved in proliferation, differentiation, and activation of macrophages (Rao, 2001). Further investigations are needed here, especially with a focus on the role of ERK1/2 in the induction of cytokines during phagocytosis. The second MAPK we focused on is $\mathrm{p} 38$. This kinase was shown to be activated by several external stimuli like TNF- $\alpha$, heat, osmotic shock, or growth factors (Freshney et al., 1994; Rouse et al., 1994). Doyle et al. proposed a model in which the activation of TLRs in macrophages leads amongst others to the activation of $\mathrm{p} 38$ resulting in the upregulation of scavenger receptors like MARCO and therefore enhanced phagocytosis (Doyle et al., 2004). In our experiments, the phosphorylation of p38 started within the first 5 min post-infection indicating an important role in the early phase of pneumococcal phagocytosis.

The activation of the aforementioned kinases during pneumococcal infection seems not to be restricted to professional phagocytes. Pneumococci were shown to interact with the cellular polymeric immunoglobulin receptor (pIgR) of respiratory epithelial cells via the pneumococcal surface protein $\mathrm{C}$ (PspC). The modulated signaling cascades resulting in uptake of the bacteria involves amongst others the PI3K, Akt, and the MAPKs ERK1/2 (Agarwal and Hammerschmidt, 2009; Agarwal et al., 2010). Furthermore, pneumococci were shown to be taken

\section{REFERENCES}

Aderem, A. (2003). Phagocytosis and the inflammatory response. J. Infect. Dis.187(Suppl. 2), S340-S345. doi: 10.1086/374747

Agarwal, V., Asmat, T. M., Dierdorf, N. I., Hauck, C. R., and Hammerschmidt, S. (2010). Polymeric immunoglobulin receptor-mediated invasion of Streptococcus pneumoniae into host cells requires a coordinate signaling of SRC family of protein-tyrosine kinases, ERK, and c-Jun N-terminal kinase. J. Biol. Chem. 285, 35615-35623. doi: 10.1074/jbc.M110.172999

Agarwal, V., and Hammerschmidt, S. (2009). Cdc42 and the phosphatidylinositol 3-kinase-Akt pathway are essential for PspC-mediated internalization of pneumococci by respiratory epithelial cells. J. Biol. Chem. 284, 19427-19436. doi: 10.1074/jbc.M109.003442

Araki, N., Johnson, M. T., and Swanson, J. A. (1996). A role for phosphoinositide 3-kinase in the completion of macropinocytosis and phagocytosis by macrophages. J. Cell Biol. 135, 1249-1260. doi: 10.1083/jcb.135.5.1249

Arbibe, L., Mira, J. P., Teusch, N., Kline, L., Guha, M., Mackman, N., et al. (2000). Toll-like receptor 2-mediated NF-kappa B activation requires a Rac1dependent pathway. Nat. Immunol. 1, 533-540. doi: 10.1038/82797

Arredouani, M., Yang, Z., Ning, Y., Qin, G., Soininen, R., Tryggvason, K., et al. (2004). The scavenger receptor MARCO is required for lung defense against up by human epithelial pharyngeal cells (Detroit 562) exploiting vitronectin as a bridging molecule to interact with $\alpha_{\mathrm{V}} \beta_{3}$ integrins. In addition to the integrin linked kinase (ILK) the PI3K plays an essential role in pneumococcal endocytosis via the vitronectin mechanism (Bergmann et al., 2009).

The analysis of further signaling cascades like the JNK, Src, and focal adhesion kinases is necessary to gain deeper insights into signaling events triggered by pneumococci during phagocytosis.

Moreover, pneumococcal infection of macrophages was shown to contribute to apoptosis (Ulett and Adderson, 2006). Therefore, it could be of great interest to analyze the participation of pneumococcal triggered cell signaling pathways on the induction of apoptosis.

Taken together, we used the model of PMA-differentiated THP-1 cells to characterize the interaction of S. pneumoniae with professional phagocytes. The relevance of the bacterial growth medium on phagocytosis as well as the time-dependent uptake and killing was demonstrated. Furthermore, insights into cell signaling processes during bacterial uptake were deciphered by using pharmacological inhibitors and performing immunoblot analysis.

\section{AUTHOR CONTRIBUTIONS}

TK was writing the paper and performed experiments. TK was the supervisor of AS. AS executed experiments, DK executed experiments, $\mathrm{SH}$ was writing the paper, supervisor of $\mathrm{DK}$, project leader.

\section{ACKNOWLEDGMENTS}

We thank Peggy Stremlow for excellent technical assistance. This work was supported by Deutsche Forschungsgemeinschaft Grant DFG HA 3125/4-2. pneumococcal pneumonia and inhaled particles. J. Exp. Med. 200, 267-272. doi: 10.1084/jem.20040731

Bergmann, S., Lang, A., Rohde, M., Agarwal, V., Rennemeier, C., Grashoff, C., et al. (2009). Integrin-linked kinase is required for vitronectin-mediated internalization of Streptococcus pneumoniae by host cells. J. Cell Sci. 122, 256-267. doi: 10.1242/jcs.035600

Bogaert, D., De Groot, R., and Hermans, P. W. (2004a). Streptococcus pneumoniae colonisation: the key to pneumococcal disease. Lancet Infect. Dis. 4, 144-154. doi: 10.1016/S1473-3099(04)00938-7

Bogaert, D., van Belkum, A., Sluijter, M., Luijendijk, A., de Groot, R., Rumke, H. C., et al. (2004b). Colonisation by Streptococcus pneumoniae and Staphylococcus aureus in healthy children. Lancet 363, 1871-1872. doi: 10.1016/S01406736(04) 16357-5

Boulton, T. G., Yancopoulos, G. D., Gregory, J. S., Slaughter, C., Moomaw, C., Hsu, J., et al. (1990). An insulin-stimulated protein kinase similar to yeast kinases involved in cell cycle control. Science 249, 64-67. doi: 10.1126/science.21 64259

Chan, T. O., Rittenhouse, S. E., and Tsichlis, P. N. (1999). AKT/PKB and other D3 phosphoinositide-regulated kinases: kinase activation by phosphoinositide-dependent phosphorylation. Annu. Rev. Biochem. 68, 965-1014. doi: 10.1146/annurev.biochem.68.1.965 
Cox, D., Tseng, C. C., Bjekic, G., and Greenberg, S. (1999). A requirement for phosphatidylinositol 3-kinase in pseudopod extension. J. Biol. Chem. 274, 1240-1247. doi: $10.1074 / \mathrm{jbc} .274 .3 .1240$

Cuenda, A., and Rousseau, S. (2007). p38 MAP-kinases pathway regulation, function and role in human diseases. Biochim. Biophys. Acta 1773, 1358-1375. doi: 10.1016/j.bbamcr.2007.03.010

Currie, A. J., Davidson, D. J., Reid, G. S., Bharya, S., MacDonald, K. L., Devon, R. S., et al. (2004). Primary immunodeficiency to pneumococcal infection due to a defect in Toll-like receptor signaling. J. Pediatr. 144, 512-518. doi: 10.1016/j.jpeds.2003.10.034

Dai, S., Rajaram, M. V., Curry, H. M., Leander, R., and Schlesinger, L. S. (2013). Fine tuning inflammation at the front door: macrophage complement receptor 3-mediates phagocytosis and immune suppression for Francisella tularensis. PLoS Pathog. 9:e1003114. doi: 10.1371/journal.ppat.1003114

del Peso, L., Gonzalez-Garcia, M., Page, C., Herrera, R., and Nunez, G. (1997). Interleukin-3-induced phosphorylation of $\mathrm{BAD}$ through the protein kinase Akt. Science 278, 687-689. doi: 10.1126/science.278.5338.687

Domin, J., and Waterfield, M. D. (1997). Using structure to define the function of phosphoinositide 3-kinase family members. FEBS Lett. 410, 91-95. doi: 10.1016/S0014-5793(97)00617-0

Doyle, S. E., O'Connell, R. M., Miranda, G. A., Vaidya, S. A., Chow, E. K., Liu, P. T., et al. (2004). Toll-like receptors induce a phagocytic gene program through p38. J. Exp. Med. 199, 81-90. doi: 10.1084/jem.20031237

Echchannaoui, H., Frei, K., Letiembre, M., Strieter, R. M., Adachi, Y., and Landmann, R. (2005). CD14 deficiency leads to increased MIP-2 production, CXCR2 expression, neutrophil transmigration, and early death in pneumococcal infection. J. Leukoc. Biol. 78, 705-715. doi: 10.1189/jlb.0205063

Engelman, J. A., Luo, J., and Cantley, L. C. (2006). The evolution of phosphatidylinositol 3-kinases as regulators of growth and metabolism. Nat. Rev. Genet. 7, 606-619. doi: 10.1038/nrg1879

Feldman, C., Cockeran, R., Jedrzejas, M. J., Mitchell, T. J., and Anderson, R. (2007). Hyaluronidase augments pneumolysin-mediated injury to human ciliated epithelium. Int. J. Infect. Dis. 11, 11-15. doi: 10.1016/j.ijid.2005.09.002

Fitzer-Attas, C. J., Lowry, M., Crowley, M. T., Finn, A. J., Meng, F., DeFranco, A. L., et al. (2000). Fcgamma receptor-mediated phagocytosis in macrophages lacking the Src family tyrosine kinases Hck, Fgr, and Lyn. J. Exp. Med. 191, 669-682. doi: $10.1084 /$ jem.191.4.669

Freeman, S. A., and Grinstein, S. (2014). Phagocytosis: receptors, signal integration, and the cytoskeleton. Immunol. Rev. 262, 193-215. doi: $10.1111 /$ imr.12212

Freshney, N. W., Rawlinson, L., Guesdon, F., Jones, E., Cowley, S., Hsuan, J., et al. (1994). Interleukin-1 activates a novel protein kinase cascade that results in the phosphorylation of Hsp27. Cell 78, 1039-1049. doi: 10.1016/00928674(94)90278-X

Gamez, G., and Hammerschmidt, S. (2012). Combat pneumococcal infections: adhesins as candidates for protein-based vaccine development. Curr. Drug Targets 13, 323-337. doi: 10.2174/138945012799 424697

Ganesan, L. P., Wei, G., Pengal, R. A., Moldovan, L., Moldovan, N., Ostrowski, M. C., et al. (2004). The serine/threonine kinase Akt Promotes Fc gamma receptormediated phagocytosis in murine macrophages through the activation of p70S6 kinase. J. Biol. Chem. 279, 54416-54425. doi: 10.1074/jbc.M408188200

Garenne, M., Ronsmans, C., and Campbell, H. (1992). The magnitude of mortality from acute respiratory infections in children under 5 years in developing countries. World Health Stat. Q. 45, 180-191.

Garin, J., Diez, R., Kieffer, S., Dermine, J. F., Duclos, S., Gagnon, E., et al. (2001). The phagosome proteome: insight into phagosome functions. J. Cell Biol. 152, 165-180. doi: 10.1083/jcb.152.1.165

Gerisch, G., Ecke, M., Schroth-Diez, B., Gerwig, S., Engel, U., Maddera, L., et al. (2009). Self-organizing actin waves as planar phagocytic cup structures. Cell Adh. Migr. 3, 373-382. doi: 10.4161/cam.3.4.9708

Ghiran, I., Barbashov, S. F., Klickstein, L. B., Tas, S. W., Jensenius, J. C., and Nicholson-Weller, A. (2000). Complement receptor $1 /$ CD35 is a receptor for mannan-binding lectin. J. Exp. Med. 192, 1797-1808. doi: 10.1084/jem.192.12.1797

Girish, V., and Vijayalakshmi, A. (2004). Affordable image analysis using NIH Image/ImageJ. Indian J. Cancer 41, 47.
Gomez, F., Ruiz, P., and Schreiber, A. D. (1994). Impaired function of macrophage Fc gamma receptors and bacterial infection in alcoholic cirrhosis. N. Engl. J. Med. 331, 1122-1128. doi: 10.1056/NEJM199410273311704

Greenberg, S., and Grinstein, S. (2002). Phagocytosis and innate immunity. Curr. Opin. Immunol. 14, 136-145. doi: 10.1016/S0952-7915(01)00309-0

Hartel, T., Klein, M., Koedel, U., Rohde, M., Petruschka, L., and Hammerschmidt, S. (2011). Impact of glutamine transporters on pneumococcal fitness under infection-related conditions. Infect. Immun. 79, 44-58. doi: 10.1128/IAI.00 855-10

Hawkins, P. T., Eguinoa, A., Qiu, R. G., Stokoe, D., Cooke, F. T., Walters, R., et al. (1995). PDGF stimulates an increase in GTP-Rac via activation of phosphoinositide 3-kinase. Curr. Biol. 5, 393-403. doi: 10.1016/S09609822(95)00080-7

Hermans, P. W., Adrian, P. V., Albert, C., Estevao, S., Hoogenboezem, T., Luijendijk, I. H., et al. (2006). The streptococcal lipoprotein rotamase A (SlrA) is a functional peptidyl-prolyl isomerase involved in pneumococcal colonization. J. Biol. Chem. 281, 968-976. doi: 10.1074/jbc.M510014200

Hussain, M., Melegaro, A., Pebody, R. G., George, R., Edmunds, W. J., Talukdar, R., et al. (2005). A longitudinal household study of Streptococcus pneumoniae nasopharyngeal carriage in a UK setting. Epidemiol. Infect. 133, 891-898. doi: $10.1017 /$ S0950268805004012

Iwasaki, A., and Medzhitov, R. (2015). Control of adaptive immunity by the innate immune system. Nat. Immunol. 16, 343-353. doi: 10.1038/ni.3123

James, S. R., Downes, C. P., Gigg, R., Grove, S. J., Holmes, A. B., and Alessi, D. R. (1996). Specific binding of the Akt-1 protein kinase to phosphatidylinositol 3,4,5-trisphosphate without subsequent activation. Biochem. J. 315( $\mathrm{Pt} \mathrm{3})$, 709-713. doi: 10.1042/bj3150709

Janeway, C. A. Jr., and Medzhitov, R. (2002). Innate immune recognition. Annu. Rev. Immunol. 20, 197-216. doi: 10.1146/annurev.immunol.20.083001.084359

Jonsson, S., Musher, D. M., Chapman, A., Goree, A., and Lawrence, E. C. (1985). Phagocytosis and killing of common bacterial pathogens of the lung by human alveolar macrophages. J. Infect. Dis. 152, 4-13. doi: 10.1093/infdis/152.1.4

Kang, Y. S., Kim, J. Y., Bruening, S. A., Pack, M., Charalambous, A., Pritsker, A., et al. (2004). The C-type lectin SIGN-R1 mediates uptake of the capsular polysaccharide of Streptococcus pneumoniae in the marginal zone of mouse spleen. Proc. Natl. Acad. Sci. U.S.A. 101, 215-220. doi: 10.1073/pnas.0307124101

Karimi, K., and Lennartz, M. R. (1998). Mitogen-activated protein kinase is activated during IgG-mediated phagocytosis, but is not required for target ingestion. Inflammation 22, 67-82. doi: 10.1023/A:1022347808042

Katso, R., Okkenhaug, K., Ahmadi, K., White, S., Timms, J., and Waterfield, M. D. (2001). Cellular function of phosphoinositide 3-kinases: implications for development, homeostasis, and cancer. Annu. Rev. Cell Dev. Biol. 17, 615-675. doi: 10.1146/annurev.cellbio.17.1.615

Kelly, S. J., and Jedrzejas, M. J. (2000). Structure and molecular mechanism of a functional form of pneumolysin: a cholesterol-dependent cytolysin from Streptococcus pneumoniae. J. Struct. Biol. 132, 72-81. doi: 10.1006/jsbi.2000.4308

Malley, R., Trzcinski, K., Srivastava, A., Thompson, C. M., Anderson, P. W., and Lipsitch, M. (2005). CD4+ T cells mediate antibody-independent acquired immunity to pneumococcal colonization. Proc. Natl. Acad. Sci. U.S.A. 102, 4848-4853. doi: 10.1073/pnas.0501254102

Manning, B. D., and Cantley, L. C. (2007). AKT/PKB signaling: navigating downstream. Cell 129, 1261-1274. doi: 10.1016/j.cell.2007.06.009

Matsumoto, A., Naito, M., Itakura, H., Ikemoto, S., Asaoka, H., Hayakawa, I., et al. (1990). Human macrophage scavenger receptors: primary structure, expression, and localization in atherosclerotic lesions. Proc. Natl. Acad. Sci. U.S.A. 87, 9133-9137. doi: 10.1073/pnas.87.23.9133

Miller, M., Dreisbach, A., Otto, A., Becher, D., Bernhardt, J., Hecker, M., et al. (2011). Mapping of interactions between human macrophages and Staphylococcus aureus reveals an involvement of MAP kinase signaling in the host defense. J. Proteome Res. 10, 4018-4032. doi: 10.1021/pr200224x

Mitchell, A. M., and Mitchell, T. J. (2010). Streptococcus pneumoniae: virulence factors and variation. Clin. Microbiol. Infect. 16, 411-418. doi: 10.1111/j.14690691.2010.03183.x

Mold, C., Rodic-Polic, B., and Du Clos, T. W. (2002). Protection from Streptococcus pneumoniae infection by $\mathrm{C}$-reactive protein and natural antibody requires 
complement but not Fc gamma receptors. J. Immunol. 168, 6375-6381. doi: 10.4049/jimmunol.168.12.6375

Monick, M. M., Carter, A. B., Robeff, P. K., Flaherty, D. M., Peterson, M. W., and Hunninghake, G. W. (2001). Lipopolysaccharide activates Akt in human alveolar macrophages resulting in nuclear accumulation and transcriptional activity of beta-catenin. J. Immunol. 166, 4713-4720. doi: 10.4049/jimmunol.166.7.4713

Noske, N., Kammerer, U., Rohde, M., and Hammerschmidt, S. (2009). Pneumococcal interaction with human dendritic cells: phagocytosis, survival, and induced adaptive immune response are manipulated by PavA. J. Immunol. 183, 1952-1963. doi: 10.4049/jimmunol.0804383

Orihuela, C. J., Radin, J. N., Sublett, J. E., Gao, G., Kaushal, D., and Tuomanen, E. I. (2004). Microarray analysis of pneumococcal gene expression during invasive disease. Infect. Immun. 72, 5582-5596. doi: 10.1128/IAI.72.10.5582-5596.2004

Pracht, D., Elm, C., Gerber, J., Bergmann, S., Rohde, M., Seiler, M., et al. (2005). PavA of Streptococcus pneumoniae modulates adherence, invasion, and meningeal inflammation. Infect. Immun. 73, 2680-2689. doi: 10.1128/IAI.73.5.2680-2689.2005

Raman, M., Chen, W., and Cobb, M. H. (2007). Differential regulation and properties of MAPKs. Oncogene 26, 3100-3112. doi: 10.1038/sj.onc.1210392

Rao, K. M. (2001). MAP kinase activation in macrophages. J. Leukoc. Biol. 69, 3-10.

Ravetch, J. V. (1997). Fc receptors. Curr. Opin. Immunol. 9, 121-125. doi: 10.1016/S0952-7915(97)80168-9

Rouse, J., Cohen, P., Trigon, S., Morange, M., Alonso-Llamazares, A., Zamanillo, D., et al. (1994). A novel kinase cascade triggered by stress and heat shock that stimulates MAPKAP kinase-2 and phosphorylation of the small heat shock proteins. Cell 78, 1027-1037. doi: 10.1016/0092-8674(94)90277-1

Schneider, C. A., Rasband, W. S., and Eliceiri, K. W. (2012). NIH Image to ImageJ: 25 years of image analysis. Nat. Methods 9, 671-675. doi: 10.1038/nmeth.2089

Schulz, C., Gierok, P., Petruschka, L., Lalk, M., Mader, U., and Hammerschmidt, S. (2014). Regulation of the arginine deiminase system by ArgR2 interferes with arginine metabolism and fitness of Streptococcus pneumoniae. mBio 5, 1061-1075. doi: 10.1128/mBio.01858-14

Schulz, C., and Hammerschmidt, S. (2013). Exploitation of physiology and metabolomics to identify pneumococcal vaccine candidates. Expert Rev. Vaccines 12, 1061-1075. doi: 10.1586/14760584.2013.824708

Silva, M. T. (2010). Neutrophils and macrophages work in concert as inducers and effectors of adaptive immunity against extracellular and intracellular microbial pathogens. J. Leukoc. Biol. 87, 805-813. doi: 10.1189/jlb.1109767

Sleeman, K. L., Griffiths, D., Shackley, F., Diggle, L., Gupta, S., Maiden, M. C., et al. (2006). Capsular serotype-specific attack rates and duration of carriage of Streptococcus pneumoniae in a population of children. J. Infect. Dis. 194, 682-688. doi: 10.1086/505710

Someya, M., Kojima, T., Ogawa, M., Ninomiya, T., Nomura, K., Takasawa, A., et al. (2013). Regulation of tight junctions by sex hormones in normal human endometrial epithelial cells and uterus cancer cell line Sawano. Cell Tissue Res. 354, 481-494. doi: 10.1007/s00441-013-1676-9

Sperandio, B., Fischer, N., and Sansonetti, P. J. (2015). Mucosal physical and chemical innate barriers: Lessons from microbial evasion strategies. Semin. Immunol. 27, 111-118. doi: 10.1016/j.smim.2015.03.011

Tang, J. (2011). Microbial metabolomics. Curr. Genomics 12, 391-403. doi: $10.2174 / 138920211797248619$
Trappetti, C., Kadioglu, A., Carter, M., Hayre, J., Iannelli, F., Pozzi, G., et al. (2009). Sialic acid: a preventable signal for pneumococcal biofilm formation, colonization, and invasion of the host. J. Infect. Dis. 199, 1497-1505. doi: 10.1086/598483

Tsuchiya, S., Yamabe, M., Yamaguchi, Y., Kobayashi, Y., Konno, T., and Tada, K. (1980). Establishment and characterization of a human acute monocytic leukemia cell line (THP-1). Int. J. Cancer 26, 171-176. doi: $10.1002 / \mathrm{ijc} .2910260208$

Ulett, G. C., and Adderson, E. E. (2006). Regulation of apoptosis by gram-positive bacteria: mechanistic diversity and consequences for immunity. Curr. Immunol. Rev. 2, 119-141. doi: 10.2174/1573395067768 43033

van Furth, R., and Cohn, Z. A. (1968). The origin and kinetics of mononuclear phagocytes. J. Exp. Med. 128, 415-435. doi: 10.1084/jem.12 8.3.415

van Furth, R., Cohn, Z. A., Hirsch, J. G., Humphrey, J. H., Spector, W. G., and Langevoort, H. L. (1972). Mononuclear phagocytic system: new classification of macrophages, monocytes and of their cell line. Bull. World Health Organ. 47, 651-658.

Voss, S., Gamez, G., and Hammerschmidt, S. (2012). Impact of pneumococcal microbial surface components recognizing adhesive matrix molecules on colonization. Mol. Oral Microbiol. 27, 246-256. doi: 10.1111/j.2041-1014.2012.00654.x

Weber, J. R., Freyer, D., Alexander, C., Schroder, N. W., Reiss, A., Kuster, C., et al. (2003). Recognition of pneumococcal peptidoglycan: an expanded, pivotal role for LPS binding protein. Immunity 19, 269-279. doi: 10.1016/S10747613(03)00205-X

Widmann, C., Gibson, S., Jarpe, M. B., and Johnson, G. L. (1999). Mitogenactivated protein kinase: conservation of a three-kinase module from yeast to human. Physiol. Rev. 79, 143-180.

Wood, W. B., Smith, M. R., and Watson, B. (1946). Studies on the mechanism of recovery in pneumococcal pneumonia: IV. The mechanism of phagocytosis in the absence of antibody. J. Exp. Med. 84, 387-402. doi: 10.1084/jem.8 4.4.387

Wullschleger, S., Loewith, R., and Hall, M. N. (2006). TOR signaling in growth and metabolism. Cell 124, 471-484. doi: 10.1016/j.cell.2006. 01.016

Yoon, S., and Seger, R. (2006). The extracellular signal-regulated kinase: multiple substrates regulate diverse cellular functions. Growth Factors 24, 21-44. doi: $10.1080 / 02699050500284218$

Conflict of Interest Statement: The authors declare that the research was conducted in the absence of any commercial or financial relationships that could be construed as a potential conflict of interest.

Copyright (C) 2016 Kohler, Scholz, Kiachludis and Hammerschmidt. This is an openaccess article distributed under the terms of the Creative Commons Attribution License (CC BY). The use, distribution or reproduction in other forums is permitted, provided the original author(s) or licensor are credited and that the original publication in this journal is cited, in accordance with accepted academic practice. No use, distribution or reproduction is permitted which does not comply with these terms. 